\title{
Predevelopment Freshwater Heads in the Glaciofluvial, Saginaw, and Marshall Aquifers in the Michigan Basin
}

\section{U.S. Geological Survey Open-File Report 95-319}

MICHIGAN BASIN REGIONAL AQUIFER-SYSTEM ANALYSIS
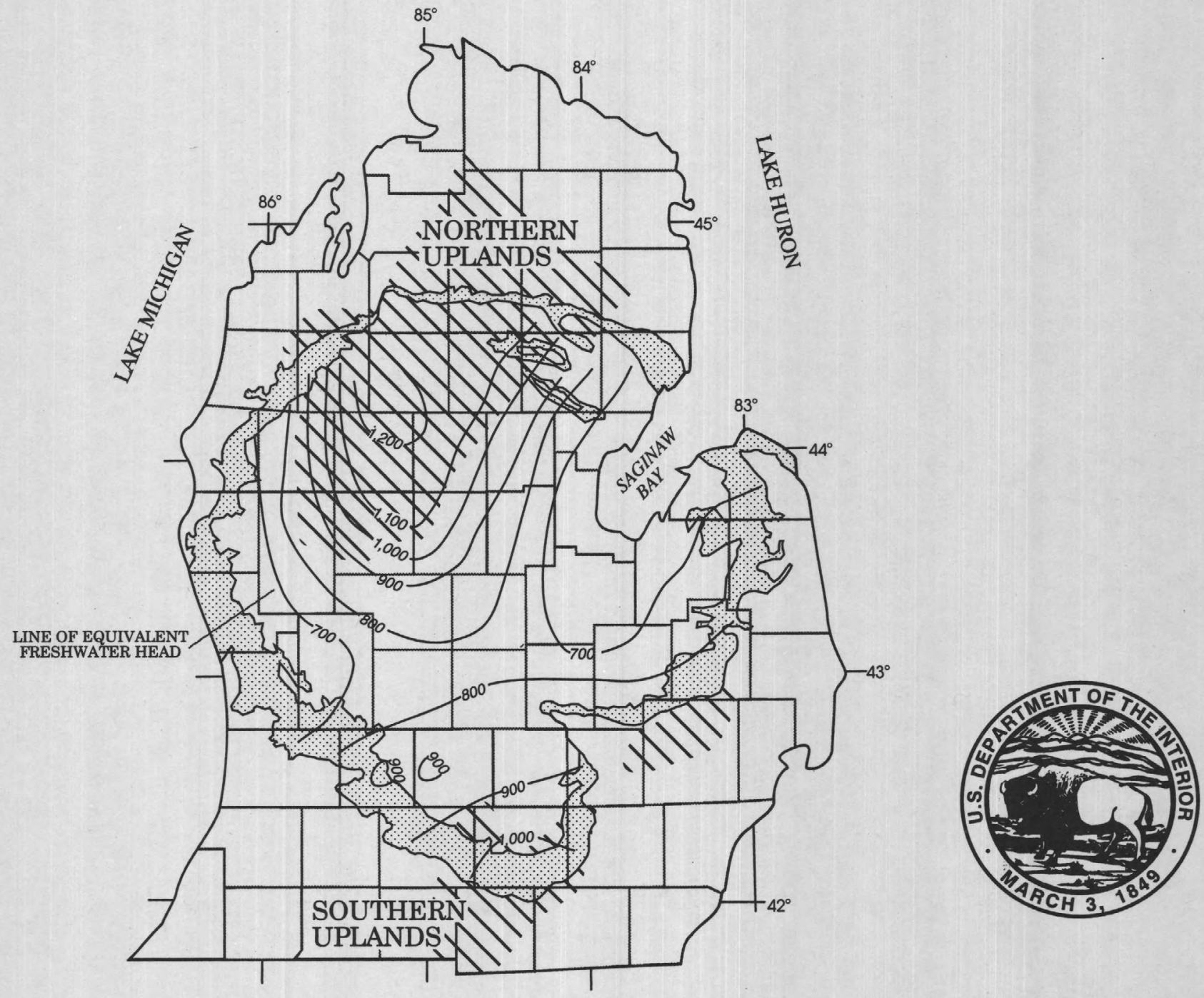

Predevelopment Freshwater Heads in the Glaciofluvial, Saginaw, and Marshall Aquifers in the Michigan Basin

By GARY BARTON, RICHARD J. MANDLE, and MATTHEW A. BALTUSIS, JR.

U.S. Geological Survey

Open-File Report 95-319

MICHIGAN BASIN REGIONAL AQUIFER-SYSTEM ANALYSIS

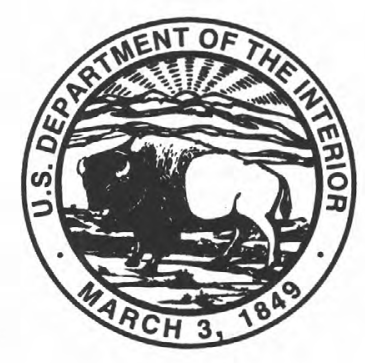




\title{
U.S. DEPARTMENT OF THE INTERIOR BRUCE BABBITT, Secretary
}

\author{
U.S. GEOLOGICAL SURVEY \\ Gordon P. Eaton, Director
}

For additional information write to:

Copies of this report can be purchased from:

District Chief

U.S. Geological Survey

Water Resources Division

6520 Mercantile Way, Suite 5 Lansing, Ml 48911-5991
U.S. Geological Survey

Branch of Information Services

Box 25286

Denver, CO 80225 


\section{CONTENTS}

Abstract

Introduction

Purpose and Scope

Geohydrologic Setting....

Previous Studies

Acknowledgments

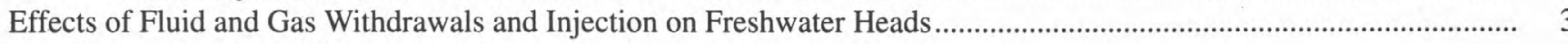

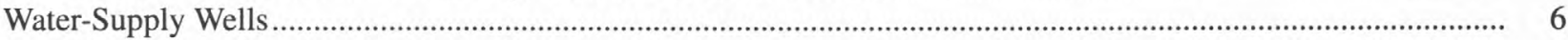

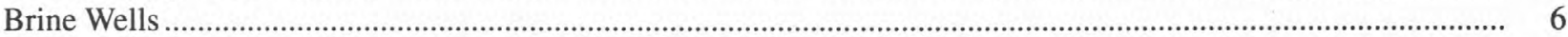

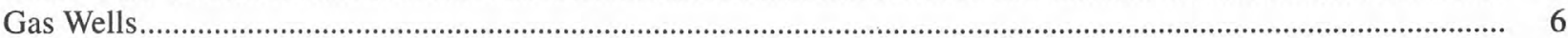

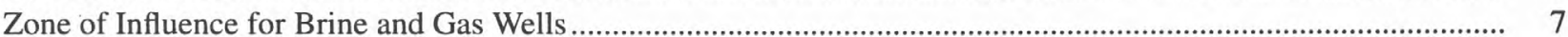

Use of Ground-Water Levels and Borehole Shut-In Pressures to Estimate Equivalent Freshwater Heads ......................... 7

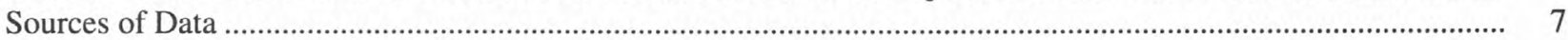

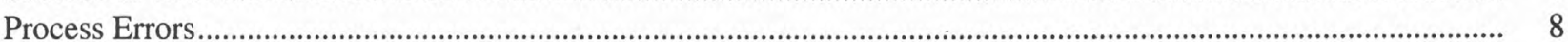

Transforming Shut-In Borehole Pressures to Equivalent Freshwater Heads ...................................................... 9

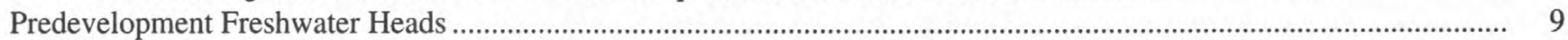

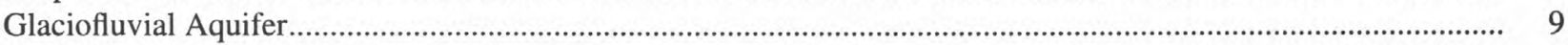

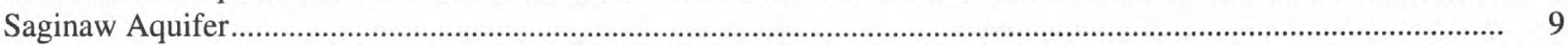

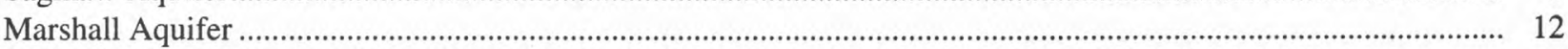

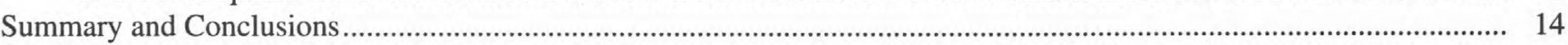

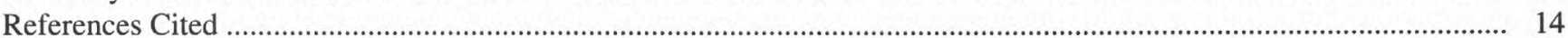

\section{FIGURES}

1,2. Maps showing:

1. Study area of the Michigan Basin Regional Aquifer System Analysis ........................................................... 2

2. Geology of the Lower Peninsula of Michigan ....................................................................................

3. Stratigraphic column and hydrogeologic characteristics, Michigan Basin .......................................................... 5

4. Graph showing depth to brine after cessation of brine withdrawal from a brine production well near Alma, Michigan that was open to the Marshall aquifer

5,6. Maps showing:

5. General water-table configuration for the glaciofluvial aquifer in the Lower Peninsula of Michigan .............. 10

6. Predevelopment freshwater heads in the Saginaw aquifer, Lower Peninsula of Michigan............................. 11

7. Graph showing depth and bottom-hole pressure in gas and water wells in the Marshall aquifer, Lower Peninsula of Michigan

8. Map showing predevelopment equivalent freshwater heads in the Marshall aquifer, Lower Peninsula of Michigan 
CONVERSION FACTORS AND VERTICAL DATUM

CONVERSION FACTORS

\begin{tabular}{rcl}
\hline Multiply & By & To obtain \\
\hline cubic foot $\left(\mathrm{ft}^{3}\right)$ & 0.02832 & cubic meter \\
foot (ft) & 0.3048 & meter \\
foot per second (ft/s) & 30.48 & centimeter per second \\
gallon (gal) & 3.785 & liter \\
inch (in.) & 25.4 & millimeter \\
million gallons per day (Mgal/d) & 0.003785 & cubic meters per day \\
pounds per square inch (lb/in $\left.{ }^{2}\right)$ & 6.895 & kilopascal \\
square foot $\left(\mathrm{ft}^{2}\right)$ & 0.09290 & square meter \\
square mile $\left(\mathrm{mi}^{2}\right)$ & 2.590 & square kilometer \\
\hline
\end{tabular}

\section{VERTICAL DATUM}

Sea level: In this report "sea level" refers to the National Geodetic Vertical Datum of 1929-a geodetic datum derived from a general adjustment of the first-order level nets of both the United States and Canada, formerly called Sea Level Datum of 1929. 


\title{
Predevelopment Freshwater Heads of the Glaciofluvial, Saginaw, and Marshall Aquifers in the Michigan Basin
}

\author{
By Gary J. Barton, Richard J. Mandle, and Matthew A. Baltusis, Jr.
}

\section{Abstract}

Maps showing predevelopment freshwater heads were developed for the major aquifers in the Michigan Basin. The Michigan Basin is an isolated, regional ground-water-flow system consisting of a glaciofluvial aquifer and three bedrock aquifers separated by confining units. The bedrock aquifers investigated are the Saginaw, ParmaBayport, and Marshall aquifers. Fractured sandstones within the bedrock aquifers comprise the principal water-bearing zones. Withdrawals from supply wells in the glaciofluvial aquifer, and more so from the Saginaw and Marshall aquifers, have lowered the potentiometric surface in several areas. The Marshall aquifer is a highly developed natural resource. Locally, extensive withdrawals of brine and natural gas from the Marshall aquifer have lowered the potentiometric surface to below pre-1890's predevelopment levels.

The maps of freshwater heads were prepared from hydraulic-head measurements made from the late 1800's through 1976. Lake and river stages also were used to prepare a water-table map.

\section{INTRODUCTION}

The study area of the Michigan Basin (RASA) includes about 22,000 $\mathrm{mi}^{2}$ of the Lower Peninsula of Michigan (fig. 1). The aquifer system in the study area consists of Mississippian and younger age consolidated and unconsolidated sediments. The Marshall Sandstone of Mississippian age, sandstones within the Grand River and Saginaw Formations of Pennsylvanian age, and glacial deposits of Pleistocene age are the major sources of ground water in the Michigan Basin. The contact between the Coldwater Shale of Mississippian age and the overlying Marshall Sandstone forms the outer boundary of the study area (fig. 1).

The purpose of the Michigan Basin RASA is to describe the hydrogeologic framework, ground-water chemistry, and regional ground-water-flow patterns in the central Lower Peninsula of Michigan (Mandle, 1986). As part of this project, maps of equivalent freshwater heads were prepared to aid in defining general paths of ground-water flow and the hydraulic gradients along these flow paths. The hydraulic gradient can be used to determine the average ground-water velocity along a given path if the local horizontal hydraulic conductivity of the aquifer and the density of the water are known.

\section{Purpose and Scope}

The purpose of this report is to describe the predevelopment water levels in the major aquifers in the central Lower Peninsula of Michigan. The report includes maps showing the regional water table in the glaciofluvial aquifer, freshwater heads for the Saginaw aquifer, and equivalent freshwater heads for the Marshall aquifer. This report is part of a series of reports prepared by the Michigan Basin RASA. 
EXPLANATION

STUDY AREA

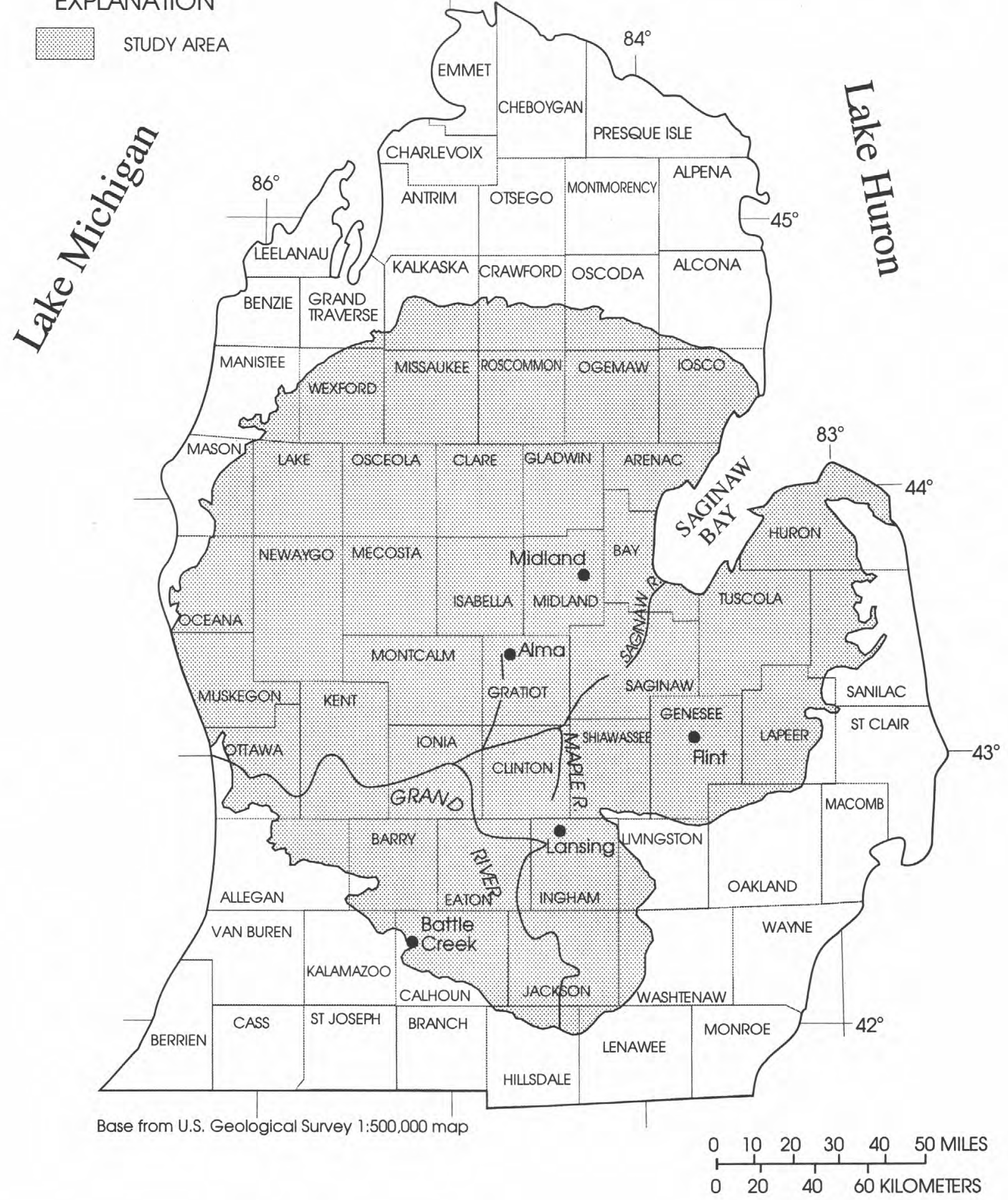

Figure 1. Study area of the Michigan Basin Regional Aquifer System Analysis. 


\section{Geohydrologic Setting}

The Michigan Basin regional aquifer system consists of the unconsolidated glaciofluvial aquifer, and three bedrock aquifers (Saginaw, Parma-Bayport, and Marshall) separated by confining units (fig. 2). The Parma-Bayport aquifer is not discussed in this report owing to insufficient hydraulic-head data. The Coldwater Shale is the base of the aquifer system (figs. 2 and 3).

Glacial deposits mantle nearly all the study area. Thicknesses range from 10 to $200 \mathrm{ft}, 200$ to $400 \mathrm{ft}$, and 400 to $1,000 \mathrm{ft}$ in the southern, central, and northern parts (Western Michigan University, 1981, pl. 15). The glaciofluvial aquifer consists primarily of thick sequences of sand and gravel but, in parts of the study area, also consists of sand and gravel layers within till or other fine-grained deposits. In this report, the uppermost aquifer is referred to as a single unit even though it consists of multiple sand and gravel layers (Westjohn and others, 1993, p. 4-6).

The Saginaw aquifer consists of lenticular sandstones whose composite thickness ranges from 0 to $370 \mathrm{ft}$ (fig. 3). "Red beds" of Upper Jurassic age overlie the aquifer in the west-central part of the study area. The "red beds" consist of mudstone and poorly consolidated red shale, gypsum, and minor amounts of sandstone (Westjohn and others, 1993, p. 6-13).

Together with fine-grained glacial and lacustrine deposits, the "red beds" form subregional confining units that separate the glaciofluvial aquifer from the underlying Saginaw aquifer.

The Marshall aquifer, the basal aquifer in the study area, includes sandstones that overlie the Coldwater confining unit, as well as sandstones that form the Stray Sandstone Member of the Michigan Formation (fig. 3). The Marshall aquifer consists of two or more permeable sandstones in the central part of the basin; but in and near areas where the aquifer is a subcrop of glacial deposits, it consists of one permeable sandstone. In areas where more than one sandstone is present, intercalated carbonate, shale, siltstone, and evaporite separate permeable sandstones. The composite thickness of permeable sandstone generally ranges from 0 to $175 \mathrm{ft}$ (fig. 3). The Marshall aquifer is regionally confined except where it is a subcrop of the glaciofluvial aquifer. Where the aquifer is confined, the water is generally brackish or saline (Westjohn, U. S. Geological Survey, oral commun., 1994).

\section{Previous Studies}

Vugrinovich (1986) used shut-in borehole pressures, fluid density, and ground-water levels to develop maps showing lines of equal variable-density heads, graphs of subsurface pressure and production depth, and maps showing hypsographic distributions of head and surface elevations. These maps and graphs were used to depict the potentiometric surfaces, under predevelopment conditions, of bedrock and glaciofluvial aquifers. The heads were not corrected to equivalent freshwater heads.

\section{Acknowledgments}

The authors greatly appreciate the assistance of Raymond Vugrinovich of the Michigan Department of Natural Resources, Geologic Survey Division, in locating and describing borehole-pressure and water-level measurements; and of Mark Nida in obtaining data from the files of the Michigan Department of Commerce, Public Service Commission.

\section{EFFECTS OF FLUID AND GAS WITHDRAWALS AND INJECTION ON FRESHWATER HEADS}

The potentiometric surface in the Marshall aquifer has declined in response to the withdrawals of brine, gas, and potable water from wells. Records of brine withdrawal are incomplete, and historical sequential water-level measurements in wells near areas of brine and gas production are generally unavailable. In a few places, brine or other fluids were injected into the Marshall aquifer. The injection caused the potentiometric surface to rise; on a regional basis, however, this rise probably is much less than the decline caused by withdrawals. 


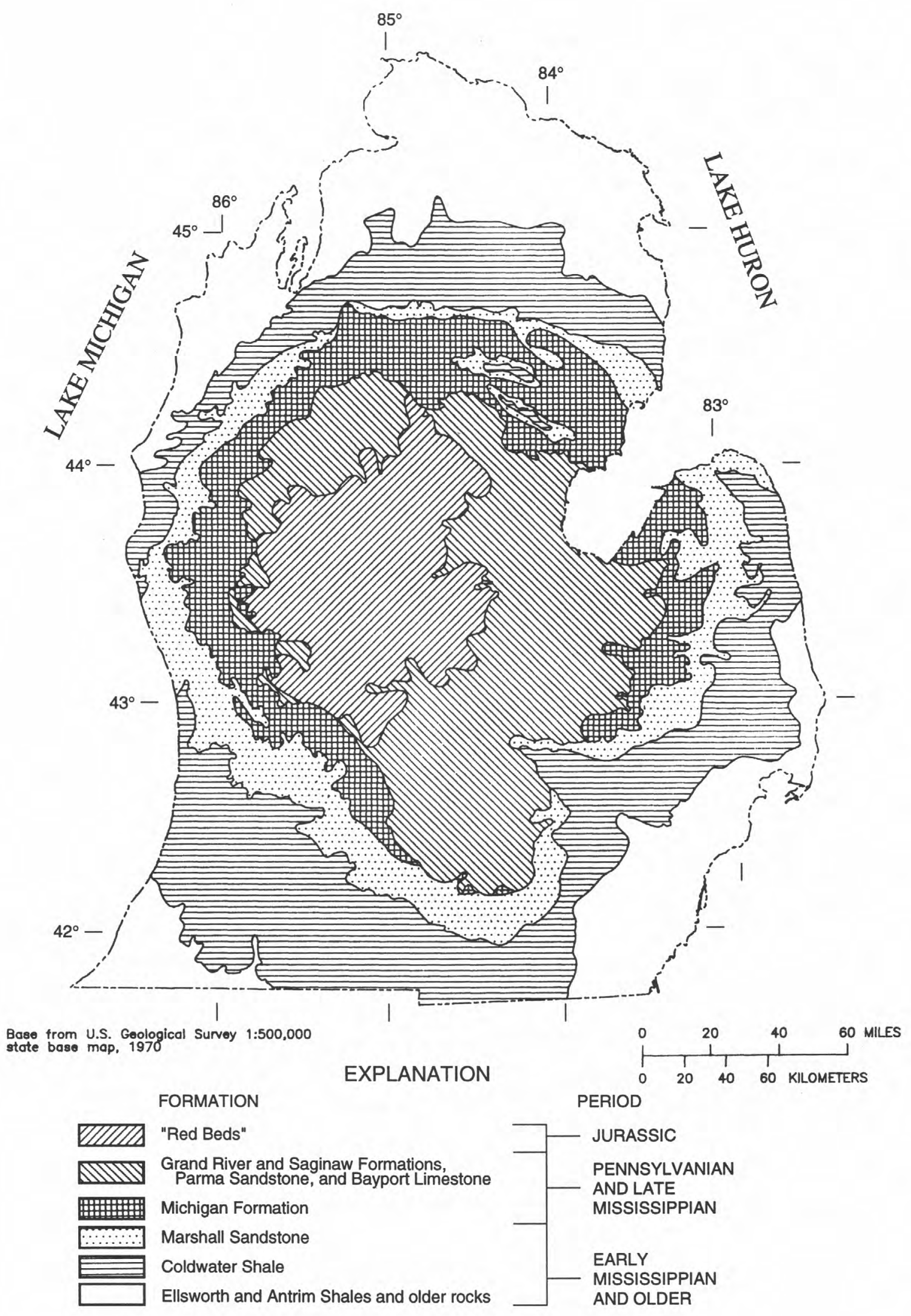

Figure 2. Geology of the Lower Peninsula of Michigan. (Modified from Martin, 1995.) 


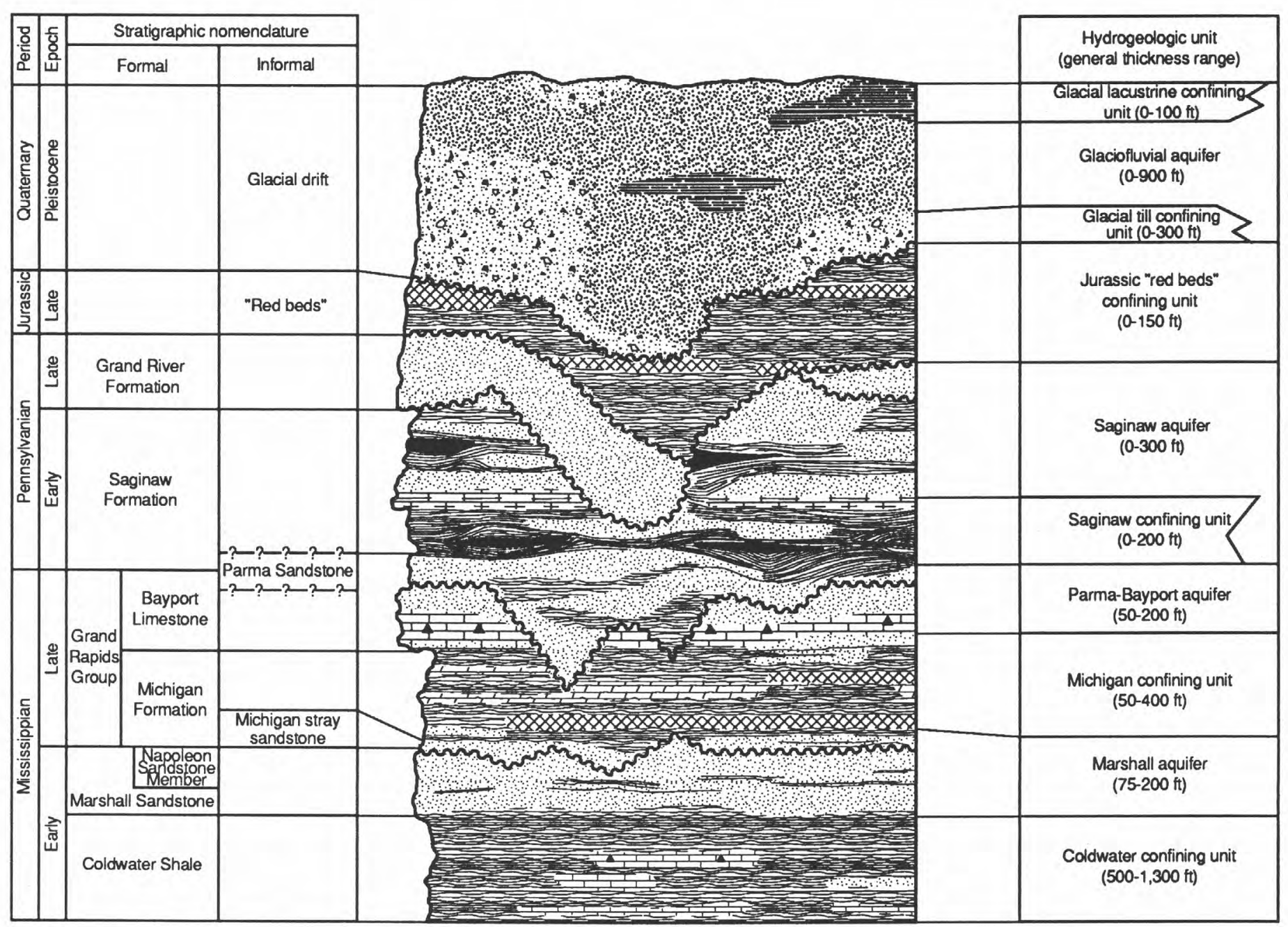

Figure 3. Stratigraphic column and hydrogeologic characteristics, Michigan Basin. (From Westjohn, 1993, fig. 2.) 
Lane (1899) and Leverett (1906, 1907) reported potable and brackish water flowing from wells in the study area. Wells flowing potable water from the Saginaw aquifer were located in Arenac, Bay, Clinton, Eaton, Genesse, Gladwin, Gratiot, Ingham, Ionia, Livingston, Saginaw, Tuscola, and Shiawassee Counties. Potable water flowing from wells in the Marshall aquifer were reported in many areas where the aquifer is a subcrop of the glacial deposits along the southern and eastern parts of the study area, including Allegan, Calhoun, Genesee, Hillsdale, Huron, Jackson, Lapeer, Livingston, Oakland, Ottawa, Washtenaw, Shiawassee, and Sanilac Counties. Lane (1902, fig. 31) presented a geologist's log of a coal exploration borehole in Midland where water from the Marshall aquifer overflowed land surface. Allen (1977) reported on several other counties where potable water flowed from wells completed in the Saginaw and Marshall aquifers, and stated that heads in many flowing wells completed in the Marshall aquifer have declined since 1900. For example, the maximum water level in a well completed in the Marshall aquifer in Battle Creek that was flowing during 1900 was $30 \mathrm{ft}$ below land surface in 1970 . Water levels in most other wells in this area have generally declined because of ground-water withdrawals; however, the declines have generally been less than $10 \mathrm{ft}$.

\section{Water-Supply Wells}

Withdrawals from water-supply wells open to the Saginaw and Marshall aquifers have lowered the potentiometric surface locally. Most of these wells have been constructed where the aquifers are subcrops of the glaciofluvial aquifer. Municipal wells have been in use since the late 1800 's. The horizontal hydraulic conductivity is much greater in the subcrop areas because here it is fracture controlled and the water is saline downdip from the subcrop where the aquifer is confined. The ratio of sandstone to shale in the Saginaw aquifer is much greater in the Lansing area than elsewhere, and the aquifer is correspondingly much more productive. Maximum reported municipal ground-water withdrawals in the study area totaled about $103 \mathrm{Mgal} / \mathrm{d}$ in 1979 (Baltusis and others, 1992). In the Lansing area (fig. 1), where the Saginaw aquifer is the principal ground-water source, a cone of depression extending more than $100 \mathrm{mi}^{2}$ has developed (Vanlier and others, 1973); water levels in the center of the cone have been as much as $160 \mathrm{ft}$ below the prepumping level. In parts of Genesse County, where the Saginaw and Marshall aquifers are used for public supplies, pumping caused the migration of water with high chloride concentration to the pumping center; some wells were abandoned (Wiitala and others, 1963, p. 59).

\section{Brine Wells}

Brine was pumped from the Marshall aquifer from the late 1800's until the 1970's for extraction of raw material to manufacture chemicals. As many as 125 brine wells in Midland, Isabella, and Gratiot Counties were operated during the late 1800's and the early 1900's (NewCombe, 1932, p. 193). Brine withdrawals generally ranged from 1.2 to $1.5 \mathrm{Mgal} / \mathrm{d}$; cumulative withdrawals approached 19,000 Mgal. In addition, a substantial volume of brine was produced with the gas in gas wells. The amount of brine produced cannot be estimated because records of brine production are generally incomplete. The brine typically was injected in the underlying formations to protect gas reservoirs in the Marshall Formation (Schoeneck, 1944, p. 21).

\section{Gas Wells}

Production of gas from the Marshall Formation began in the 1930's. Gas production is reported as volume in gas reservoirs for an average reservoir pressure of $650 \mathrm{lb} / \mathrm{in}^{2}$ and $65^{\circ} \mathrm{F}$. By 1982, 1,900,000 Mgal of gas had been produced from these units (Michigan Department of Natural Resources, 1984). Gas production peaked during the 1940's at about 1,600 Mgal/d and declined to less than $0.1 \mathrm{Mgal} / \mathrm{d}$ by the early 1980 's. Beginning in 1941, some old gas fields were converted to gas-storage fields. 


\section{Zone of Influence for Brine and Gas Wells}

The zone of influence and lowering of the potentiometric surface in the Marshall aquifer by the pumping of brine and gas from wells is largely a local phenomenon (NewCombe, 1932, p. 193 and fig. 35), probably because matrix-controlled horizontal hydraulic conductivity of the aquifer is low at depths greater than $400 \mathrm{ft}$ below land surface. The median horizontal hydraulic conductivity of the aquifer, excluding gas reservoirs, is approximately $10^{-6} \mathrm{ft} / \mathrm{s}$ (David Westjohn, U.S. Geological Survey, oral commun., 1993). Brine-production wells were generally constructed in areas of low matrix-controlled horizontal hydraulic conductivity. Heads in some areas are returning to predevelopment levels. For example, when brine withdrawals ceased in 1957, the brine level in a well located near Alma, Midland, Mich. (fig. 4) increased $127 \mathrm{ft}$ at nearly a constant rate until 1966, when brine-level measurements ceased (K.E. Vanlier, U.S. Geological Survey, written commun., 1967). The low rate of increase of brine level in this well may reflect the aquifer's low horizontal hydraulic conductivity. An unknown amount of fluid was also injected into the formation about $3 \mathrm{mi}$ away. The injection also may have had a slight effect on the brine level.

\section{USE OF GROUND-WATER LEVELS AND BOREHOLE SHUT-IN PRESSURES TO ESTIMATE EQUIVALENT FRESHWATER HEADS}

\section{Sources of Data}

Altitudes of the water-table map for the glaciofluvial aquifer were determined from water-level measurements reported on drillers' logs for about 14,000 wells installed between 1969 and 1976 and from lake and river stages determined from topographic maps over the entire Lower Peninsula (Mandle and Westjohn, 1989). The ground-water-level

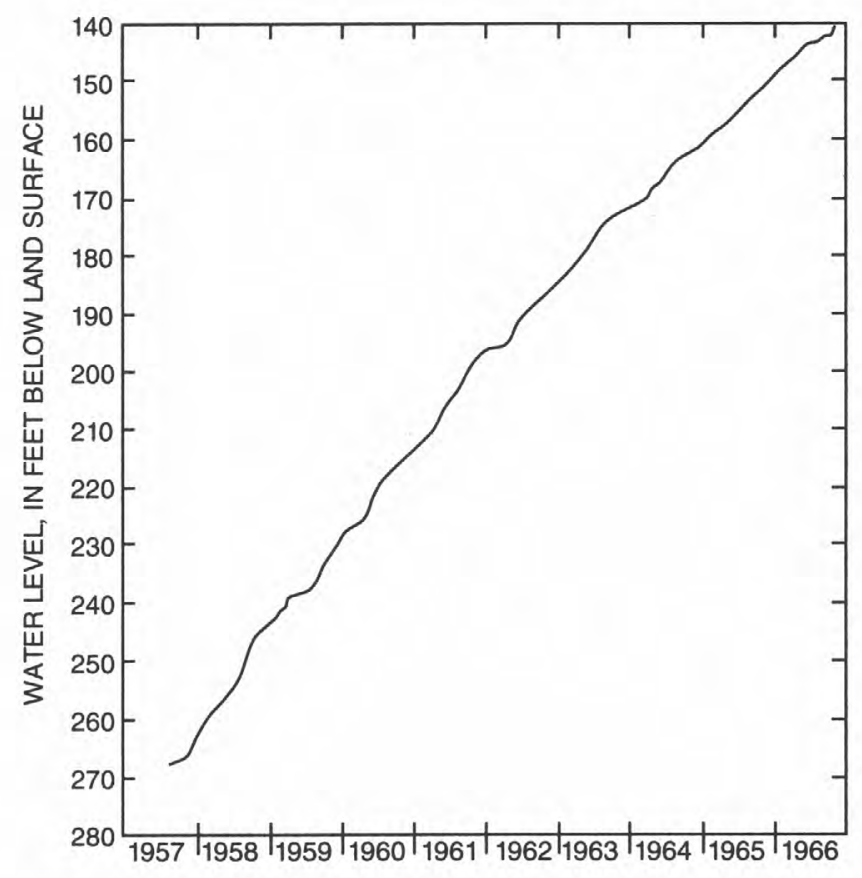

Figure 4. Depth to brine after cessation of brine withdrawal from a brine-production well near Alma, Michigan, that was open to the Marshall aquifer. (From K.E. Vanlier and Wood, U.S. Geological Survey, written commun., 1967.)

measurements are on file with the Michigan Department of Natural Resources and in the U.S. Geological Survey's Ground Water Site Inventory data base.

Determination of the predevelopment freshwater heads for the Saginaw aquifer was based on water-level measurements at 54 wells. The data, reported in Lane (1899), Leverett (1906, 1907), and in Cooper (1904), were compiled by Raymond Vugrinovich (Michigan Department of Natural Resources, written commun., 1984). Other measurements compiled by Vugrinovich, excluding those from Lane (1899) and Leverett (1906, 1907), are primarily from water levels measured by water well drillers shortly after installation of domestic and supply wells during 1930-59. 
Determinations of predevelopment equivalent freshwater heads for the Marshall aquifer were based on water levels in five exploratory wells drilled for this project and on data compiled by Raymond Vugrinovich (Michigan Department of Natural Resources, written commun., 1984). The data include measurements reported by Lane (1899) and Leverett $(1906,1907)$. The data base consists of hydraulic-head measurements at 89 wells. Vugrinovich compiled four types of measurements used for estimating hydraulic head (1) water levels measured by water-well drillers during the installation of 17 domestic and supply wells, dating from the late 1800's; (2) initial measurements of shutin pressure made at the production tree of 13 discovery gas wells at distance from producing gas fields, dating from the 1930's and 1940's; (3) water levels measured by drillers during cable-tool drilling of 39 exploratory gas wells, to provide areal coverage in the northern and western parts of the study area, dating from the 1930's and 1940's; and, (4) initial and final shut-in pressures measured during drill-stem tests of discovery wells (Bredehoeft,1965) at distance from producing gas fields, dating from the 1930's and 1940's. In addition, initial and final shut-in pressures measured from the 1930 's through the 1950's during drill-stem tests of 10 gas wells were obtained from the Michigan Department of Commerce. Measurements of shut-in pressure were transformed to equivalent freshwater hydraulic heads (as described in "Transforming Borehole Shut-In Pressures to Equivalent Freshwater Heads" later in this report).

\section{Process Errors}

Measurement of shut-in pressure and water level in wells commonly results in large errors. In addition, error is inherent in the handling and transcribing of records. The total of all these errors, which is the difference between the equivalent freshwater head and the actual head at the mapped location, is called the process error (Weiss, 1990). Where possible, the hydraulic-head measurements of two or more wells in close proximity were compared to identify and eliminate erroneous data. Because of process errors and the small number and limited areal distribution of predevelopment hydraulic-head measurements, the maps in this report show only an approximation of the actual predevelopment potentiometric surfaces.

Some water levels measured by water-well drillers during installation of wells may not reflect hydraulic head in the aquifer near a well. For example, low-yield wells may require days or weeks before water levels in the borehole and the aquifer reach equilibrium. Whether water levels in the borehole approached equilibrium with heads in the aquifer cannot be determined because no sequential measurements are available. In addition, water levels measured in wells are not corrected for seasonal waterlevel fluctuations.

Water levels reported by cable-tool drillers were measured only in exploratory oil or gas wells in areas where additional nearby wells were to be drilled. In these areas, determining the depth of water-bearing zones was helpful for anticipating casing requirements. When water-bearing zones are penetrated during drilling with cable tools, the rate of deepening the borehole is drastically reduced. Drillers typically measured the water level in the borehole before installing casing to seal off the water-bearing zone(s). Drillers often had to wait 24 hours for casing to arrive at the drill site. During this waiting period, water levels in the borehole would approach equilibrium with heads in the bedrock aquifer. However, no sequential measurements are on record to ascertain how closely equilibrium was approached (Raymond Vugrinovich, Michigan Department of Natural Resources, oral commun., 1993).

The initial shut-in pressures measured at the production tree of discovery gas wells probably approach the undisturbed formation pressure; however, this does not necessarily apply to drill-stem tests. Generally, drill-stem tests are conducted over too short a time to establish a pressure equilibrium between the well bore and the formation, especially in test-hole intervals of low horizontal hydraulic conductivity. Raymond Vugrinovich (Michigan Department of Natural Resources, written commun., 1984) used Horner's method (Horner, 1951) to analyze pressure 
buildup and recovery during drill-stem tests in estimating the undisturbed formation pressure. The accuracy of the estimate is related to the length of the shut-in period of the drill-stem test. In addition, the measurement of undisturbed formation pressure where well depths exceed $1,000 \mathrm{ft}$ is difficult; undetectable problems can result in erroneous measurements. For example, the quality of the pressure measurement is controlled by the integrity of the seal imparted by straddle packers on the annulus.

\section{Transforming Borehole Shut-In Pressures To Equivalent Freshwater Heads}

Shut-in pressures measured at wellheads were converted (Craft and Hawkins, 1959, modified equation 1.12) to bottom-hole pressures (BHP) by use of equation 1 and were transformed to equivalent freshwater head $(E F H)$ by use of equation 2 . Shut-in pressures obtained during drill-stem tests were transformed to $E F H$ by use of equation 2 .

$$
\begin{gathered}
B H P=P a+W H P+0.25(W H P / 100)(D / 100) \\
E F H=B H P \times 2.308 \mathrm{ft} \text { of } \mathrm{H}_{2} 0 / \mathrm{psi}+D
\end{gathered}
$$

where

$\mathrm{Pa}$ is atmospheric pressure (used in cases where $\mathrm{Pa}$ was not included in the shut-in pressure measurement), in pounds per square inch;

WHP is pressure at wellhead, in pounds per square inch; and,

$D$ is elevation of midpoint of drill-stem test tool or producing zone, in feet.

The hydrostatic-pressure gradient of freshwater is approximately $0.433\left(\mathrm{lb} / \mathrm{in}^{2}\right) / \mathrm{ft}$; for brines, the gradient can range from about $0.465\left(\mathrm{lb} / \mathrm{in}^{2}\right) / \mathrm{ft}$ for dissolved-solids concentration of about $80,000 \mathrm{mg} / \mathrm{L}$ to $0.496\left(\mathrm{lb} / \mathrm{in}^{2}\right) / \mathrm{ft}$ for a dissolved-solids concentration of about $200,000 \mathrm{mg} / \mathrm{L}$.

\section{PREDEVELOPMENT FRESHWATER HEADS}

\section{Glaciofluvial Aquifer}

The water-table map for the glaciofluvial aquifer (fig. 5) shows two areas of high water-table altitudes in which separate subregional flow systems exist: the Northern and Southern Uplands. Water-table altitudes in the Northern Uplands exceed 1,200 ft and are as much as about $1,000 \mathrm{ft}$ in the Southern Uplands. The water table slopes away from the upland areas toward Lakes Michigan, Huron, and Erie and toward an elongated northeast-southwest depression in the water table across the Lower Peninsula. The depression is in the proglacial Grand River Valley, the site of the present day Grand, Maple and Saginaw Rivers (fig. 1). Generalized ground-water flow directions, inferred from this water-table map, show that water in the glacial deposits moves from upland areas to lowland areas and discharges to Lakes Michigan, Huron, and Erie and to stream tributaries to these lakes including the Grand, Maple, and Saginaw Rivers (Mandle and Westjohn, 1989).

\section{Saginaw Aquifer}

The map of predevelopment freshwater heads (fig. 6) indicates that topography of the land surface controls flow in the Saginaw aquifer. The altitude of the potentiometric surface in the Northern Uplands exceeds $1,000 \mathrm{ft}$ in Wexford and Missaukee Counties, and in the Southern Uplands exceeds $900 \mathrm{ft}$. Ground water flows from uplands to lowlands and discharges to Saginaw Bay or the Grand, Maple, and Saginaw Rivers or their tributaries. Regional hydraulic gradients are low: from the Northern Uplands to Saginaw Bay is 0.0015 and from the Southern Uplands to Saginaw Bay is 0.0008 . The Saginaw aquifer is regionally confined by shale within the Saginaw Formation, Jurassic "red beds," and tills of low permeability. Confinement is evident from the areal distribution of flowing wells in the Saginaw aquifer (Allen, 1977; Leverett, 1906 and 1907). 


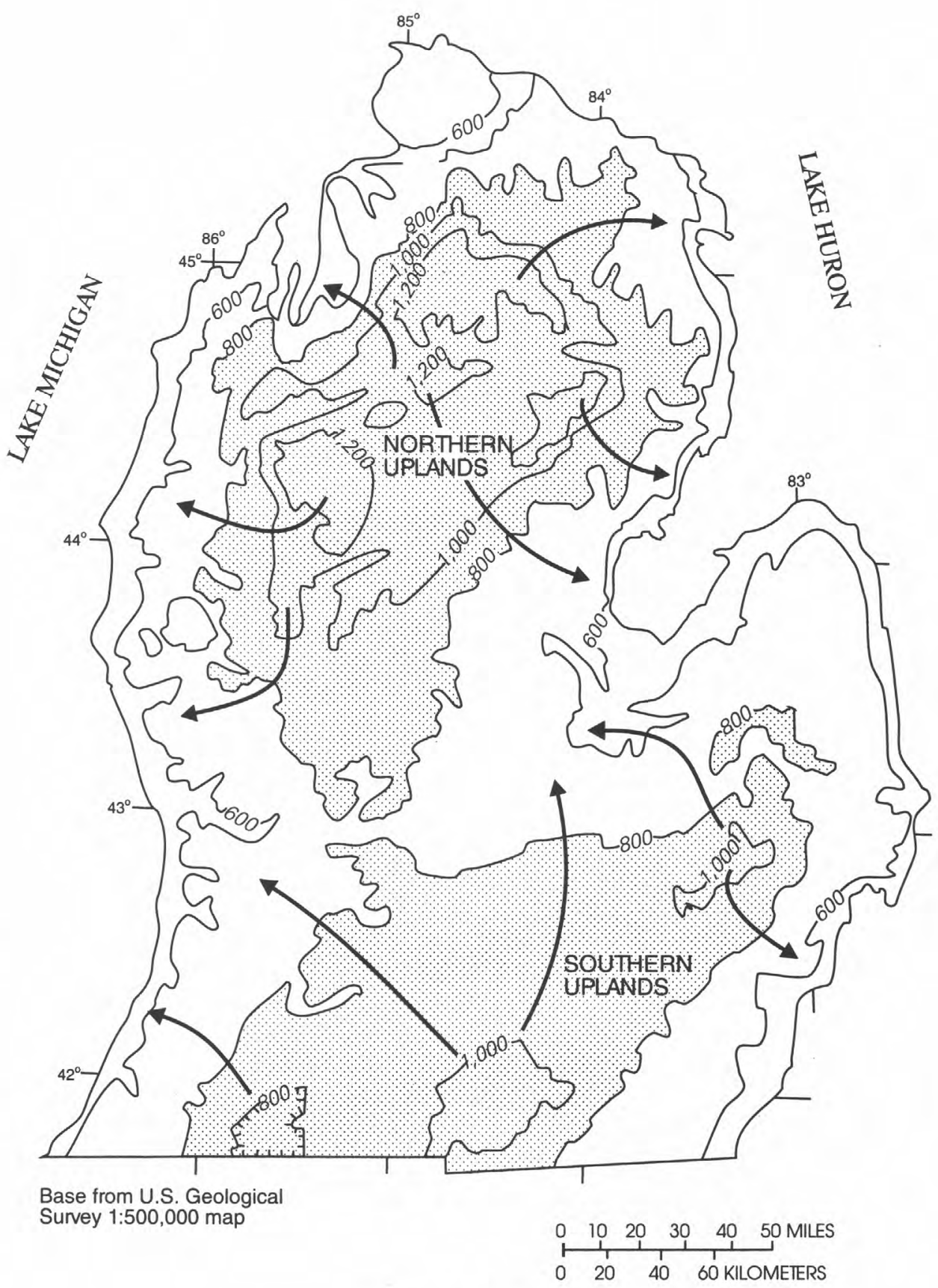

\section{EXPLANATION}

AREA WHERE WATER-TABLE ALTITUDE IS GREATER THAN 800 FEET ABOVE SEA LEVEL

- - WATER-TABLE CONTOUR--Shows equal altitude of water table. Hachure indicates depression. Contour interval 200 feet. Datum is sea level

$\longrightarrow$ GROUND-WATER FLOW--Arrow indicates direction of flow

Figure 5. General water-table configuration for the glaciofluvial aquifer in the Lower Peninsula of Michigan. (Modified from Mandle and Westjohn, 1989, fig. 10.) 


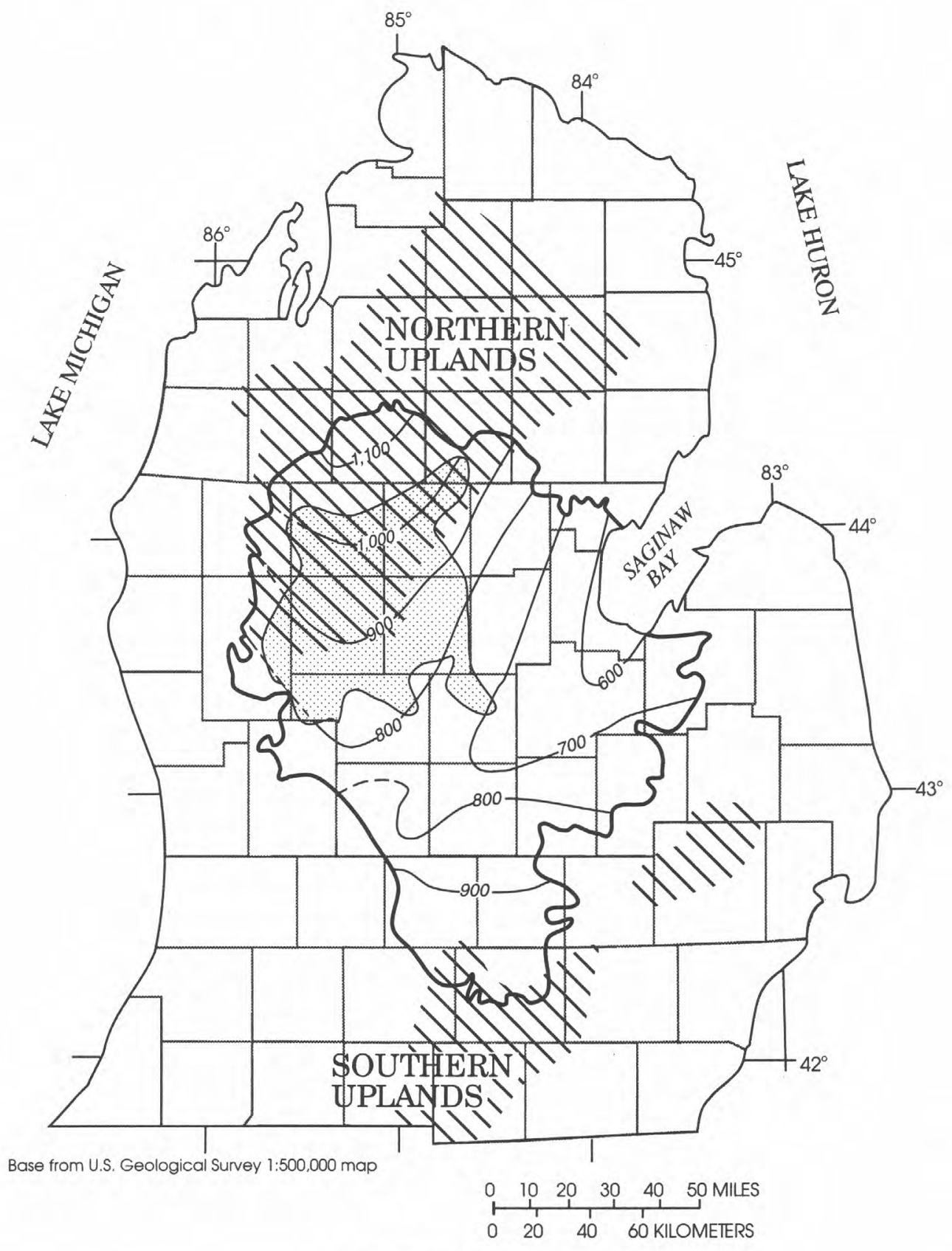

EXPLANATION

SUBCROP FOR JURASSIC RED BEDS

- 800 - LINE OF EQUAL HYDRAULIC HEAD CORRECTED TO FRESHWATER DENSITY

BOUNDARY OF SUBCROP OF SAGINAW FORMATION (WESTJOHN AND WEAVER, 1996a)

Figure 6. Predevelopment freshwater heads in the Saginaw aquifer, Lower Peninsula of Michigan. 


\section{Marshall Aquifer}

The Marshall aquifer is slightly underpressured. Bottom-hole pressures at 85 percent of the wells are less than estimates based on the hydrostatic pressure gradient for brine (fig. 7). At depths less than $500 \mathrm{ft}$, where ground water is fresh or saline depending on location of the well, bottom-hole pressures exceed estimates based on the hydrostatic pressure gradient for freshwater in less than 25 percent of wells. In overpressured formations, hydrostatic pressure at a given depth is greater than normal; whereas in underpressured formations, hydrostatic pressure at a given depth is less than normal.

The altitude of the equivalent freshwater potentiometric surface in the Northern Uplands exceeds $1,200 \mathrm{ft}$ in Wexford, Missaukee, Osceola, and Clare
Counties, and in the Southern Uplands exceeds $1,000 \mathrm{ft}$ in Calhoun, Jackson, Washtenaw, Lenawee, and Hillsdale Counties (fig. 8). Hydraulic heads gradually decline toward the interior of the basin and toward Lakes Michigan and Huron. In some subcrop areas, such as near Battle Creek (Vanlier, 1966), hydraulic heads decline toward the perimeter of the basin because a local-flow system dominates: ground water flows toward the south in contrast to the northwesterly regional-flow direction. Regional hydraulic gradients are low; however, gradients in the northern part of the basin are approximately 3 times those in the southern part. Regional hydraulic gradients from the Northern Uplands to Saginaw Bay are about 0.002 and from the Southern Uplands to Lake Michigan are about 0.0006 .

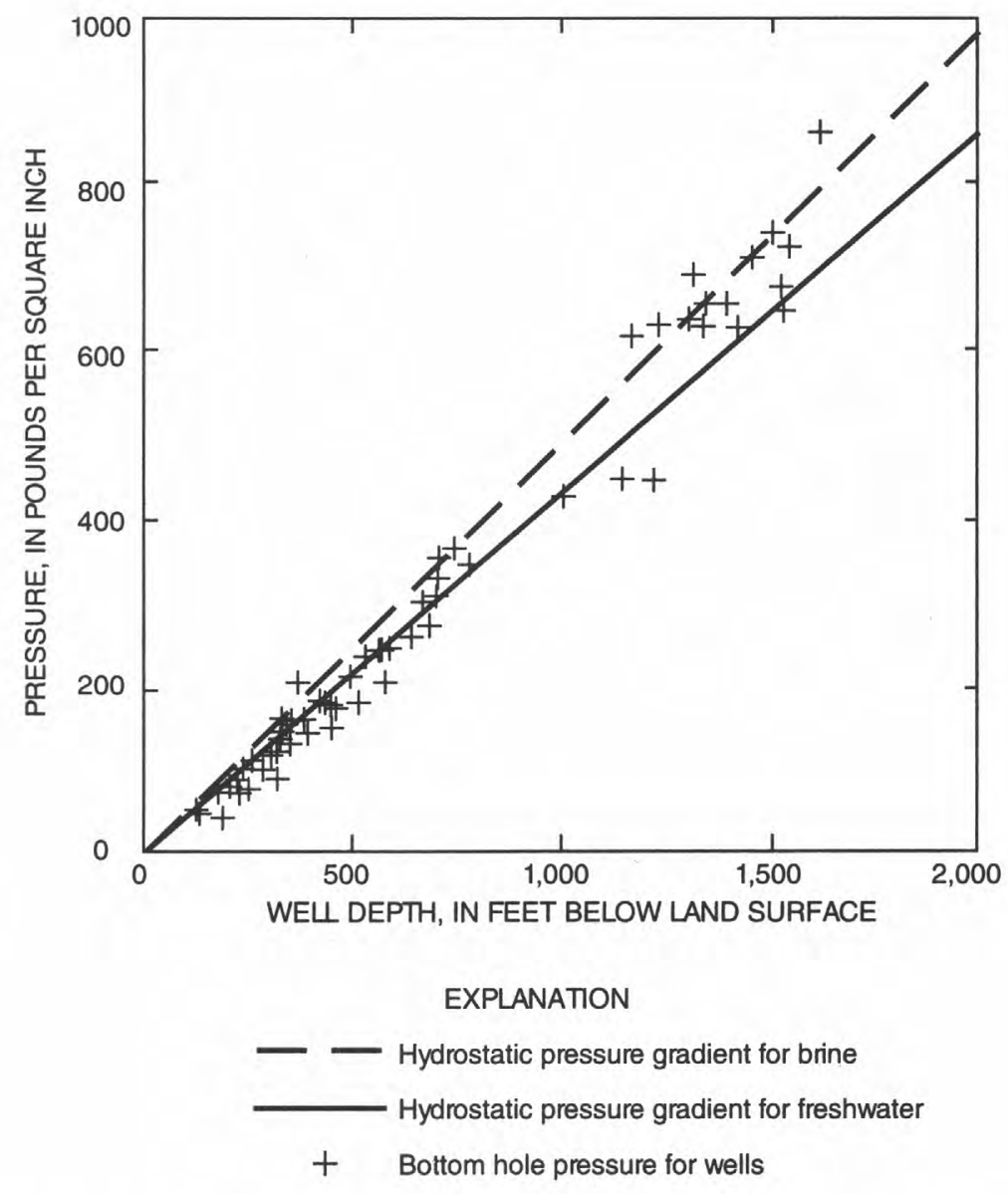

Figure 7. Depth and bottom-hole pressure in gas and water wells in the Marshall aquifer, Lower Peninsula of Michigan. 


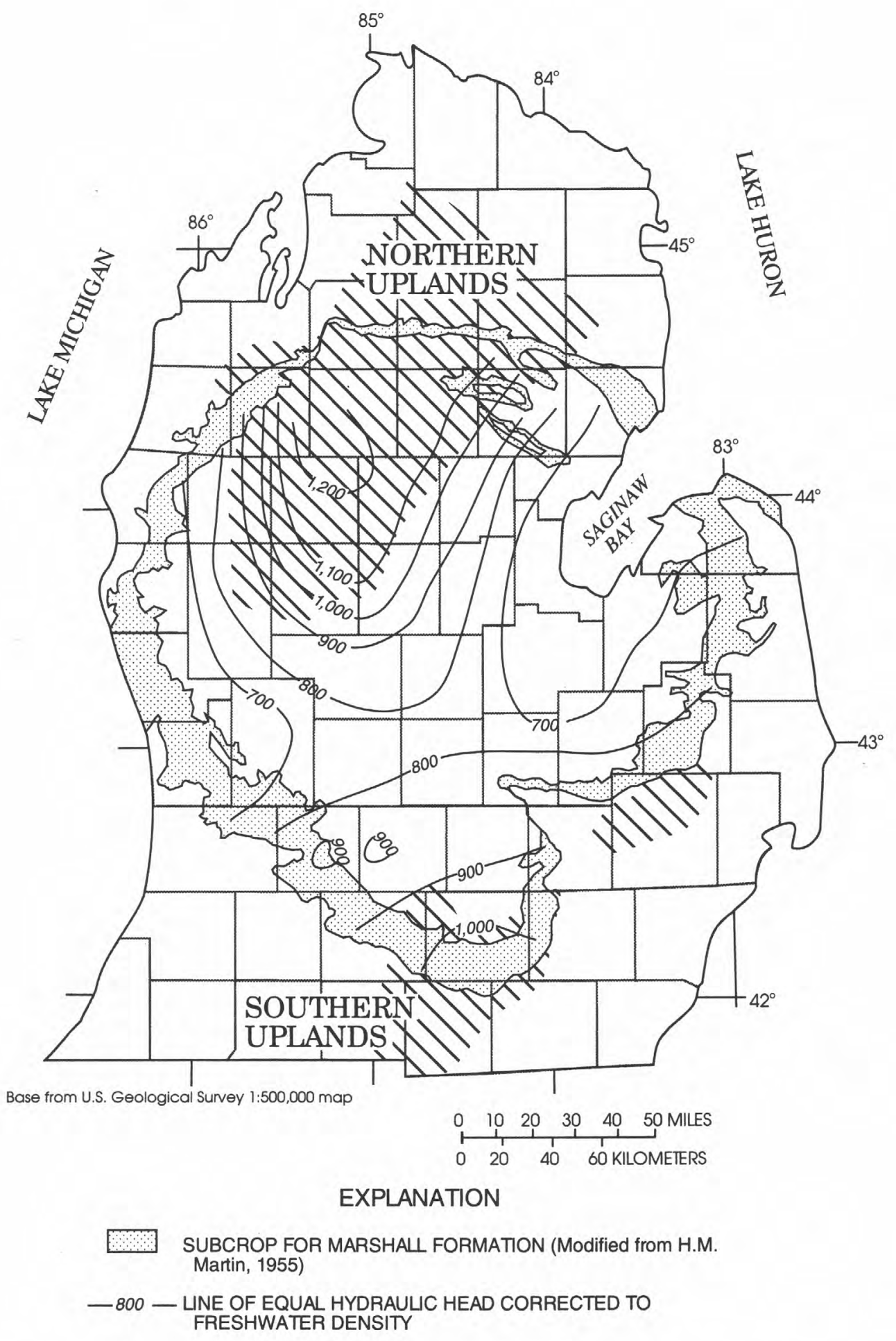

Figure 8. Predevelopment equivalent freshwater heads in the Marshall aquifer, Lower Peninsula of Michigan. 
SUMMARY AND CONCLUSIONS

Maps showing predevelopment freshwater heads were developed for the major aquifers in the Michigan Basin. The Michigan Basin is an isolated, regional ground-water-flow system consisting of a glaciofluvial aquifer and three bedrock aquifers separated by confining units. The bedrock aquifers investigated are the Saginaw, Parma-Bayport and Marshall aquifers. Fractured sandstones within the bedrock aquifers comprise the principal water-bearing zones.

Withdrawals from water-supply wells in the glaciofluvial aquifer, and especially in the Saginaw and Marshall aquifers have lowered the potentiometric surface locally. The Marshall aquifer is a highly developed natural resource. Locally, extensive withdrawals of brine and natural gas have lowered the potentiometric surface below pre-1890's levels. Brine was pumped from the late 1800's until the 1970's for extraction of raw material to manufacture chemicals. Cumulative withdrawals approached 19,000 Mgal. Drilling and production of gas began in the 1930's. By 1982, $1,900,000 \mathrm{Mgal}$ of gas had been produced. A substantial volume of brine was produced with the gas. The brine typically was injected in the underlying formations to protect gas reservoirs. Some old gas fields were converted to gas-storage fields beginning in 1941.

Because of the small number and limited areal distribution of predevelopment hydraulic-head measurements and the magnitude of process errors associated with the hydraulic-head measurements, the maps in this report are an approximation of the actual predevelopment potentiometric surfaces.

Water-table altitudes in the glaciofluvial aquifer are relatively high in the Northern and Southern Uplands. Water-table altitudes exceed 1,200 $\mathrm{ft}$ in the Northern Uplands and are about 1,000 ft in the Southern Uplands. Ground water in glacial deposits flows from uplands downgradient to lowland areas and discharges to Lakes Michigan, Huron, and Erie and to tributaries to these lakes.
The altitude of the potentiometric surface in the Saginaw aquifer in the Northern Uplands exceeds $1,000 \mathrm{ft}$ and exceeds $1,000 \mathrm{ft}$ in the Southern Uplands. Ground water flows from uplands to lowlands and to Saginaw Bay. Regional hydraulic gradient from the Northern Uplands to Saginaw Bay is 0.0015 and from the Southern Uplands to Saginaw Bay is 0.0008 . The Saginaw aquifer is regionally confined where it is overlain with Jurassic "red beds" and dense, impermeable tills.

The altitude of the equivalent freshwater potentiometric surface of the Marshall Aquifer in the Northern Uplands exceeds 1,000 ft in Jackson, Lenawee, and Hillsdale Counties. Hydraulic heads gradually decline toward the interior of the basin and toward Lakes Michigan and Huron. In some subcrop areas, such as near Battle Creek, hydraulic heads decline toward the perimeter of the basin because a local-flow system dominates: ground water flows toward the south in contrast to the northwesterly regional-flow direction. Regional gradients are low; however, gradients in the northern part of the basin are approximately 3 times those in the southern part. Regional hydraulic gradients from the Northern Uplands to Saginaw Bay are about 0.002 and from the Southern Uplands to Lake Michigan are about 0.0006 .

\section{REFERENCES CITED}

Allen, W.B., 1977, Flowing wells in Michigan 1974: Michigan Department of Natural Resources, Water Information Series Report 2, 27 p.

Baltusis, M.A., Quigley, M.F., and Mandle, R.J., 1992, Municipal ground-water development and withdrawals in the central Lower Peninsula of Michigan, 1870-1987; U.S. Geological Survey Open-File Report 91-215, 89 p.

Bredehoeft, J.D., 1965, The drill-stem test-the petroleum industry's deep-well pumping test: Ground Water, v. 3, no. 3, 6 p. 
Cooper, W.F., 1904, Well records in Lower Michigan, in Fuller, M. L., Geologist in charge, Contributions to the hydrology of eastern United States: U.S. Geological Survey Water- Supply and Irrigation Paper 102, p. 489-512.

Craft, B.C., and Hawkins, M.F., 1959, Applied petroleum reservoir engineering: Englewood Cliffs, N.J., Prentice-Hall Inc., 437 p.

Horner, D.R., 1951, Pressure buildup in wells: proceeding from Third World Petroleum Congress, Section III, p. 503.

Lane, A.C., 1899, Water Resources of the Lower Peninsula of Michigan: U.S. Geological Survey Water-Supply Paper 30, 97 p. 1902, The northern interior coal field: U.S. Geological Survey Annual Report, v. 27, part 3, p. 313-331.

Leverett, Frank, 1906, Flowing wells and municipal water supplies in the southern portion of the Southern Peninsula of Michigan: U.S. Geological Survey, Water-Supply Paper 182, 292 p. 1907 , Flowing wells and municipal water supplies in the northern portion of the Southern Peninsula of Michigan: U.S. Geological Survey, Water-Supply Paper 183, 393 p.

Mandle, R.J., 1986, Plan of study for the Regional Aquifer System Analysis of the Michigan Basin: U.S. Geological Survey Open-File Report 86-494, $23 \mathrm{p}$.

Mandle, R.J., and Westjohn, D.B., 1989, Geohydrologic framework and ground-water flow in the Michigan Basin, in Swain L.A., and Johnson, A.I., eds., Regional aquifer systems of the United States, aquifers of the Midwestern area: American Water Resources Association Monograph Series No. 13, p. 83-109.

Martin, H.M., 1955, Map of the surface formations of the southern peninsula of Michigan: Michigan Geological Survey, Publication 49, scale 1:500,000, 1 sheet.

Michigan Department of Natural Resources, 1984, Annual statistical summary of Michigan oil and gas fields - 1982: Michigan Geological Survey, Report 38, 25 p.
NewCombe, R.B., 1932, Oil and gas fields of Michigan, a discussion of depositional and structural features of the Michigan basin: State of Michigan Department of Conservation, Geological Survey Division, Publication 38, Geological Series 32, p. 193.

Schoeneck, W.E., 1944, Injection of water into underground reservoirs in the State of Michigan: proceedings from Twenty-fifth annual meeting of the American Petroleum Institute, $22 \mathrm{p}$.

Vanlier, K.E., 1966, Ground-water resources of the Battle Creek area, Michigan: Michigan Department of Natural Resources, Geological Survey Division, Water Investigation 4, 52 p.

Vanlier, K.E., Wood, W.W., and Brunett, J.O., 1973, Water-supply development and management alternatives for Clinton, Eaton, and Ingham Counties, Michigan: U. S. Geological Survey Water-Supply Paper 1969, 111 p.

Vugrinovich, Raymond, 1986, Patterns of regional subsurface fluid movement in the Michigan basin: Michigan Department of Natural Resources, Geological Survey Division, Open-File Report, 86-6, 27 p.

Weiss, Emanuel, 1990, Regional ground-water flow in upper and middle Paleozoic rocks in southeastern Utah and adjacent parts of Arizona, Colorado, and New Mexico: U.S. Geological Survey WaterResources Investigations Report 90-4079, 57 p.

Western Michigan University, Department of Geology, 1981, Hydrogeologic Atlas of Michigan: U.S. Environmental Protection Agency Underground Injection Control Program, scale 1:500,000, 35 sheets.

Westjohn, D.B., Weaver, T.L., and Zacharias, K.F., 1994, Hydrogeology of Pleistocene glacial deposits and Jurassic "red beds" in the central lower Peninsula of Michigan: U.S. Geological Survey Water-Resources Investigations Report 934152, $57 \mathrm{p}$.

Wiitala, S.W., Vanlier, K.E., and Krieger, R.A., 1963, Water resources of the Flint area, Michigan: U.S. Geological Survey Water-Supply Paper 1499-E, $86 \mathrm{p}$. 


District Chief,

Michigan District

U.S. Geological Survey

Water Resources Division

6520 Mercantile Way, Suite 5

Lansing, MI 48911-5991

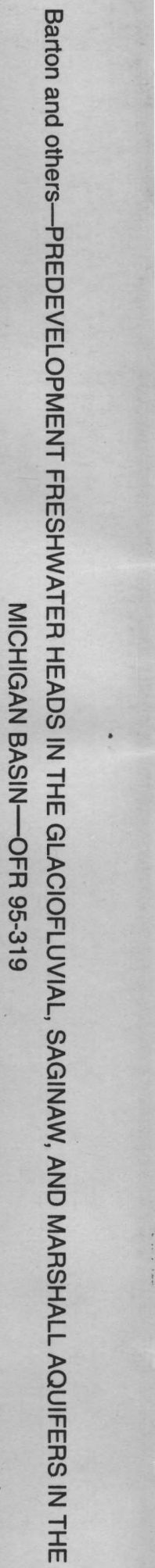

